\title{
SERVICE LIFE PREDICTION OF PIER FOR THE EXISTING REINFORCED CONCETE BRIDGES IN CHLORIDE-LADEN ENVIRONMENT
}

\author{
Ming-Te Liang \\ Department of Civil Engineering, China Institute of Technology, Taipei 115, Taiwan, R.O.C., mtliang@cc.chit.edu.tw \\ Ran Huang \\ Department of Harbor and River Engineeing, National Taiwan Ocean University, Keelung 20224, Taiwan, R.O.C. \\ Shen-An Feng \\ Department of Harbor and River Engineeing, National Taiwan Ocean University, Keelung 20224, Taiwan, R.O.C. \\ Chi-Jang Yeh \\ Sinotech Engineering Consultants Ltd., Taipei 105, Taiwan. R.O.C
}

Follow this and additional works at: https://jmstt.ntou.edu.tw/journal

Part of the Civil and Environmental Engineering Commons

\section{Recommended Citation}

Liang, Ming-Te; Huang, Ran; Feng, Shen-An; and Yeh, Chi-Jang (2009) "SERVICE LIFE PREDICTION OF PIER FOR THE EXISTING REINFORCED CONCETE BRIDGES IN CHLORIDE-LADEN ENVIRONMENT," Journal of Marine Science and Technology. Vol. 17: Iss. 4, Article 9.

DOI: $10.51400 / 2709-6998.1988$

Available at: https://jmstt.ntou.edu.tw/journal/vol17/iss4/9

This Research Article is brought to you for free and open access by Journal of Marine Science and Technology. It has been accepted for inclusion in Journal of Marine Science and Technology by an authorized editor of Journal of Marine Science and Technology. 
SERVICE LIFE PREDICTION OF PIER FOR THE EXISTING REINFORCED CONCETE BRIDGES IN CHLORIDE-LADEN ENVIRONMENT

Acknowledgements

The authors wish to thank the financial support of the National Science Council under contract NSC-95-2221-E-157-007. 


\title{
SERVICE LIFE PREDICTION OF PIER FOR THE EXISTING REINFORCED CONCETE BRIDGES IN CHLORIDE-LADEN ENVIRONMENT
}

\author{
Ming-Te Liang*, Ran Huang**, Shen-An Feng**, and Chi-Jang Yeh***
}

Key words: bridge, corrosion, pier, reinforced concrete, service life prediction.

\begin{abstract}
The prediction method of service life for bridge structures is played an important role of bridge management system. In this paper, the mathematical modeling was to study the servise life prediction of pier for existing reinforced concrete (RC) bridge exposed to chloride environment. The corrosion process has three stages, the initiation time $\left(t_{c}\right)$, the depassivation time $\left(t_{p}\right)$, and the corrosion (propagation) time $\left(t_{c o r r}\right)$. The total service life of pier for the existing RC bridge can be expressed as $t=t_{c}+t_{p}+t_{c o r r}$. Many mathematical models were applied to predicting each value of the $t_{c}, t_{p}$, and $t_{c o r r}$. The Fick's second law, the average of Bazant and Proposed methods, and the modified Bazant method are suggested to estimate the values of $t_{c}, t_{p}, t_{c o r r}$, respectively. The Tzyh-chyang and Dah-duh RC bridges in Taiwan were provided illustrative examples for the modeling approaches and service life of predictions. The predicted results used mathematical models may be reasonable for the pier service life of the existing Tzyh-chyang and Dah-duh RC bridges. The results of present study may help to offer a basis for repair, strengthening, and demolition of existing RC bridges.
\end{abstract}

\section{INTRODUCTION}

In the important infrastructure in any country, concrete and reinforced concrete (RC) is one of the most widely used construction materials all over the world. Many building, housing, and industrial structures are constructed of RC. Most infrastructures make use of concrete extensively, such as dams,

Paper submitted 04/09/08; accepted 12/13/08. Author for correspondence: Ming-Te Liang (e-mail: mtliang@cc.chit.edu.tw).

*Department of Civil Engineering, China Institute of Technology, Taipei 115, Taiwan, R.O.C.

**Department of Harbor and River Engineeing, National Taiwan Ocean University, Keelung 20224, Taiwan, R.O.C.

***Sinotech Engineering Consultants Ltd., Taipei 105, Taiwan. R.O.C. airports, coastal embankments, thermal power or nuclear energy plant, road and railway bridges, harbors and wharfs. Nevertheless, if these structures are exposed long-term to a bad environment which is of chloride ions, or carbon dioxide, or sulfate dioxide, then their service lives will be reduced. The safety of concrete or RC structures during employment needs to be taken into consideration. Moreover, the durability of concrete or RC structures have to be investigated. A worthwhile subject for study would be to set up firmly a complete evaluation method for reasonally calculating the service life of $\mathrm{RC}$ structures and for exactly furnishing judgment for repair, stengthening, or demolition.

A great deal of literature about the service life prediction for building materials and components, concrete, and RC structures was made a summary by Liang et al. [14]. However, some literature pertinent to this acticle should be introduced. Bazant [2, 3] built a simple and important physical model for steel corrosion in concrete. On the basis of Bazent's theory, the $\mathrm{RC}$ corrosion problem can be formed as an initial-boundaryvalue problem with mathematical equation. Accroding to the theory of elasticity, Bazent established two classical formulas for calculating depassivation time $\left(t_{p}\right)$ and corrosion (or propagation) time $\left(t_{c o r r}\right)$. The depassivation time is defined as depassivation normally provided to the steel by the alkaline hydrated cement matrix is destroyed locally loading to pitting corrosion. The corrosion time extends from the time when corrosion products form to the stage where they generate sufficient stress to disrupt the concrete cover by cracking or spalling, or when local attack on the reinforcement becomes sufficiently severe to impair its load-carrying capacity. It is worthy to point out that based on corrosion control Bazant derived the $\mathrm{t}_{\mathrm{p}}$ formula by a parabolic a parameter $\mathrm{Cl}^{-}$concentration. Furthermore, Liang et al. [14] pointed out that the parameter $\Delta D$ (increment of steel diameter) in formula of $t_{\text {corr }}$ derived by Bazent [3] has been made a mistake. Liang et al. [14] have offered the accurete formula and called the modified Bazant method.

Cady and Weyers [5] employed Bazant's model to evaluate the time to deterioration initiation, deterioration rate, and the time to rehabilitation for concrete bridge decks. They pointed out that the time to cracking has ranged between two and five 


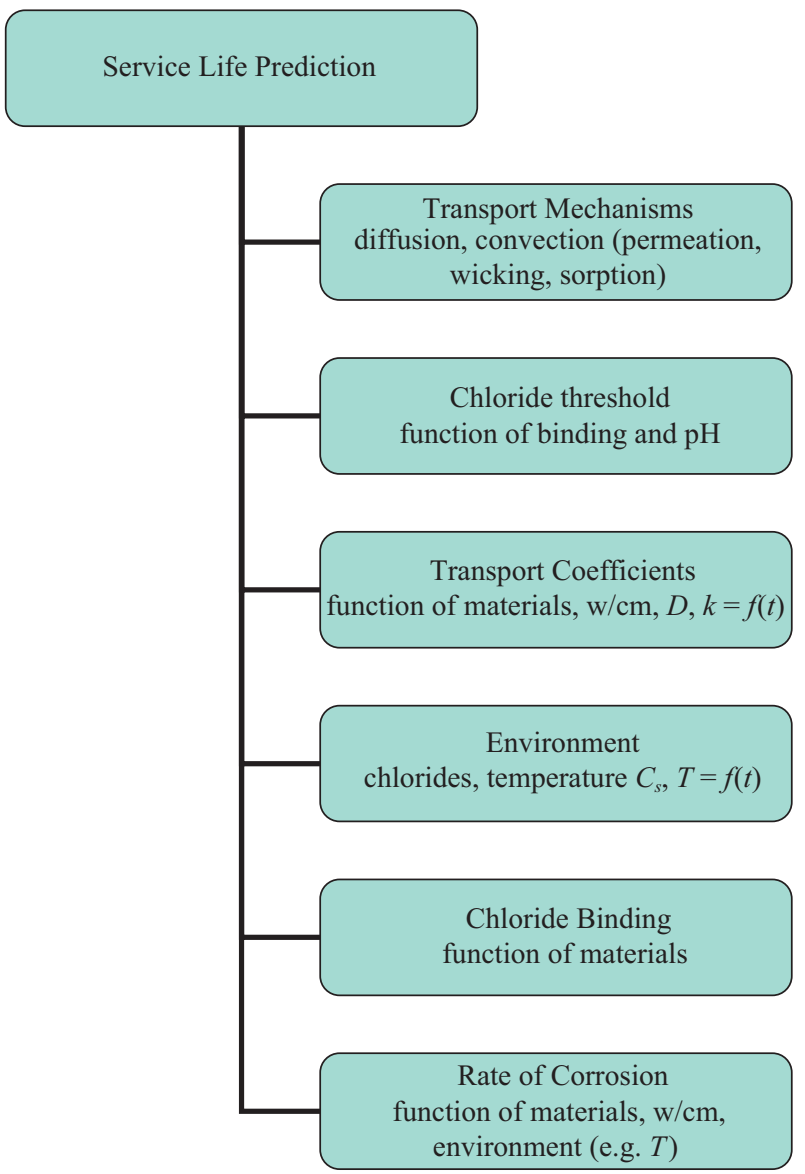

Fig. 1. Issues related to service life prediction.

years. Subramanian and Wheat [20] used Bazant's model to predict time of $t_{p}$ in a chloride environment. Liu and Miau [16] predicted the $t_{p}$, the corrosion cracking time, the breaking time of bond between concrete area steel, and the steel area losing time according to the Bazant model. Clifton $[6,7,8]$ pointed out that the five methods of expenience, deduction, accelerated testing, mathematical modeling, reliability, and stochastic concept can be used to predict the service life of concrete. On the basis of Fick's second law of linear diffusion, Weyers [22] derived a practical formula for calculating the time-to-initiate corrosion. On the authority of elesticity, Liu [17] and Liu and Weyers [18] established an empirical formula for calculating the time-to-cracking. The corrosion-cracking model is dependent on the cover depth, properties of the concrete and steel/concrete interface, type of corrosion products, and the size of the reinforcing steel and is a function of the critical weight of rust products and corrosion rate. Boddy et al. [4] provided issues related to service life prediction as sketched in Fig. 1.

Although these studies have provided much valuable application on the service life prediction for the concrete or RC structures to date, no theoretical studies have been carried out concerning the depassivation time derived by linear relation for the chloride concentration. The purpose of this paper was to estimate the service lives of piers for two existing RC bridges in chloride-laden environments using several mathematical models. The result of present study may provide a useful reference for repair, strengthening and demolition of existing $\mathrm{RC}$ bridges.

\section{ELECTROCHEMICAL PROCESSES CAUSING CHLORIDE-ION INGRESS}

When the concrete or RC structures were contaminated by the chloride-ion, they were reduced the alkalinity of the water solution in the pores of concrete. This can be caused by water dilution that accompanies cracking. Moreover, the whole or partial passive film around the steel surface would be broken or depassivated. The steel surface at different positions will make a potentially large difference and form anode and cathode as an electrochemical cell which is a kind of electrochemical process. Based on a common sense, under the constant environment of oxide and water, the steel are going to corrosion. Generally speaking, the corrosion type is a sort of streak. This implies that corrosion distributes itself on a large area of steel surface. Nevertheless, the corrosion depth is not large due to concrete with the high alkalinity environment. The corrosion process can be described by chemical reaction. The electrode reaction can be expressed as [2]

$$
\mathrm{Fe} \rightarrow \mathrm{Fe}^{2+}+2 e^{-} \quad(\text { at anode surface })
$$

$$
\mathrm{O}_{2}+2 \mathrm{H}_{2} \mathrm{O}+4 e^{-} \rightarrow 4 \mathrm{OH}^{-} \text {(at cathode surface) }
$$

where $e^{-}=$election.

The next chemical processes at the anode surface are

$$
\begin{gathered}
\mathrm{Fe}^{2+}+2 \mathrm{OH}^{-} \rightarrow \mathrm{Fe}(\mathrm{OH})_{2} \quad \text { (anode) } \\
4 \mathrm{Fe}(\mathrm{OH})_{2}+\mathrm{O}_{2}+2 \mathrm{H}_{2} \mathrm{O} \rightarrow 4 \mathrm{Fe}(\mathrm{OH})_{3} \text { (anode) }
\end{gathered}
$$

Failure may occur due to corrosion damage. If undergone of the steel bars is large (say, $s>6 D, D=$ steel diameter), we may propose that the failure mode is made up of planar cracks of $45^{\circ}$ inclination, emanating from opposite points on the surface of the steel bar. This phenomenon was described by Bazant [2] and Liang et al. [14].

\section{PREDICTION METHOD OF SERVICE LIFE}

The deterioration process of RC structure undergone corrosion media attack is sketched in Fig. 2 [21]. The corrosion processes in Fig. 2 are regarded as three stages, initiation time $\left(t_{c}\right)$, depassivation time $\left(t_{p}\right)$, and corrosion (or propagation) time $\left(t_{c o r r}\right)$. The initiation time is defined as the time for chloride ions to penetrate from the concrete surface to the surface 
Table l. Prediction method for corrosion initiation, depassivation, and propagation time.

\begin{tabular}{|c|c|c|c|}
\hline Time & Prediction method & Formula & Reference \\
\hline \multirow{4}{*}{$\begin{array}{l}\text { Initiation } \\
\text { time, } t_{c}\end{array}$} & Fick's 2nd Law & $C(x, t)=C_{o} \operatorname{erfc} \frac{x}{\sqrt{4 D_{c} t_{c}}}$ & Crank [11] \\
\hline & Guirguis & $t_{c}=\frac{L}{\lambda D_{c}}$ & Guirguis [12] \\
\hline & Hookham & $t_{c}=K_{c} K_{e} x^{2}+K_{a} x$ & Hookham [13] \\
\hline & AJMF & $C(x, t)=k \sqrt{t}\left\{e^{\frac{x^{2}}{4 D_{c} t}}-\left[\frac{x \sqrt{\pi}}{2 \sqrt{D_{c} t}} \operatorname{erfc}\left(\frac{x}{2 \sqrt{D_{c} t}}\right)\right]\right\}$ & Amey et al. [1] \\
\hline \multirow{4}{*}{$\begin{array}{l}\text { Depassivation } \\
\quad \text { time, } t_{p}\end{array}$} & Bazant & $t_{p}=\frac{1}{12 D}$ & Bazant [3] \\
\hline & Proposed & $t_{p}=\frac{1}{4 D} \frac{L}{\sqrt{\sigma^{*}}}$ & Proposed \\
\hline & ME & $t_{\text {corr }}=\frac{\delta \rho_{s t} Z F}{A i}$ & Mangat and Elgarf [19] \\
\hline & Bazant & $t_{\text {corr }}=\rho_{\text {cor }} \frac{D}{s} \frac{\Delta D}{j_{r}}, \Delta D=2 f_{t}^{\prime} 2 \frac{L}{D} \delta_{p p}$ & Bazant [2] \\
\hline \multirow[t]{3}{*}{$\begin{array}{l}\text { Propagation } \\
\text { time, } t_{\text {corr }}\end{array}$} & Modified Bazant & $t_{c o r r}=\rho_{\text {cor }} \frac{D}{s} \frac{\Delta D^{*}}{j_{r}}, \Delta D^{*}=f_{t}^{\prime}\left[2\left(\frac{L}{D}+1\right)\right] \delta_{p p}$ & Liang et al. [14] \\
\hline & $\mathrm{CW}$ & $t_{\text {corr }}=2 \sim 5$ years & Cady and Weyers [5] \\
\hline & Weyers & $t_{\text {corr }}=\frac{W_{c r i t}^{2}}{2 k_{p}}$ & Weyers [22] \\
\hline
\end{tabular}

of the passive film. The degree of deterioration (i.e., ordinate), $D_{d}$, in Fig. 2 can be defined as

$$
D_{d}=1-\frac{x}{10}
$$

where $x$ is the integrity of RC structure. The value of $x$ ranges from zero to ten. For instance, if the RC structure is free of corrosion damage then the value of $x$ is ten. Thus, the degree of deterioration is zero.

The total service life of RC structures can be expressed in terms of

$$
t=t_{c}+t_{p}+t_{\text {corr }}
$$

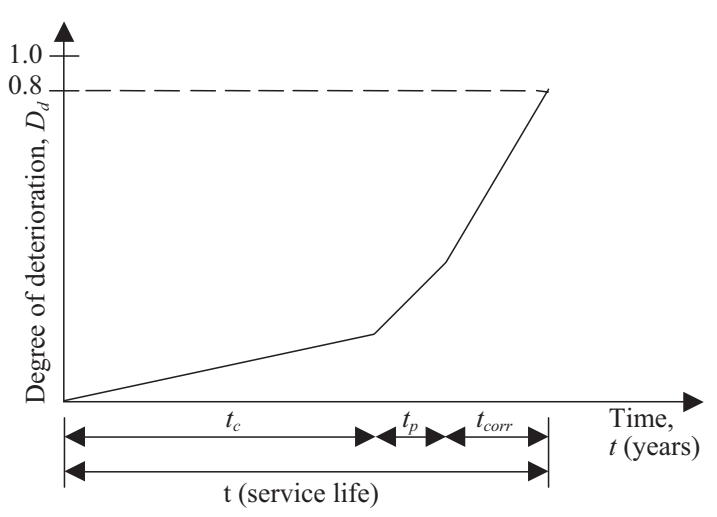

Fig. 2. Deterioration Process of reinforced concrete structures due to corrosion. 
Table 2. Overall structural conditions of Tzyh-chyang bridge.

\begin{tabular}{cl}
\hline \multicolumn{1}{c}{ Item } & \multicolumn{1}{c}{ Description } \\
\hline $\begin{array}{c}\text { Date of completed } \\
\text { construction }\end{array}$ & This bridge was completed in 1980. \\
\hline Bridge site & $\begin{array}{l}\text { This bridge locates 34K + 558 of Taiwan-19 } \\
\text { line and strides over the Jwo-shosi river for } \\
\text { connecting the Chang-hua and Yun-lin coun- } \\
\text { ties. }\end{array}$ \\
\hline
\end{tabular}

AASHT01973 road bridge standard specifiDesign specification cation and ACI318-71 concrete design specification.

The superstructure is constructed by the sim-

\begin{tabular}{ll}
\hline Superstructure & $\begin{array}{l}\text { The superstructure is constructed by the sim- } \\
\text { ple support I-type beam of prestressed con- } \\
\text { crete. This bridge has } 48 \text { holes, total length } \\
2224 \mathrm{~m} \text {, and width } 14.8 \mathrm{~m} .\end{array}$ \\
\hline The substructure is a kind of V-type concrete \\
framework. Friction pile was adopted as foun- \\
dation and of length $33 \mathrm{~m}$. The prestressed \\
pile was designed by the method of preten- \\
sion work.
\end{tabular}

Cover thickness of steel

Bridge deck: $2.5 \mathrm{~cm}$; Beam: $4 \mathrm{~cm}$; Pier: $5 \mathrm{~cm}$.

Drainage equipment of bridge deck: Accumulated water on bridge deck during raining due to some discharge holes which are clogged. The cracks of pile cap of pier: Part of pile cap with cracks. However, these cracks are less Evaluation of than concrete cover.

bridge status Expansion joint: Expansion joints and bridge decks have damage phenomena due to frequent transportation.

Superstructure: Bridge deck have longitudinal cracks.

Substructure: Some piers have a few cracks.

According to (2) and using the values of $t_{p}, t_{c}$, and $t_{c o r r}$, we can predict the service life of RC structures. The prediction method for $t_{p}, t_{c}$, and $t_{c o r r}$, are listed in Table 1.

In Table 1, we provide a proposed method for calculating the depassivation time $t_{p}$. In this study, the chloride concentration is considered as the mechanism of corrosion control. Hence, the variable of permeability depth can be expressed as a declined straight line. The derivation process is stated in detail in the Appendix.

\section{ILLUSTRATIVE EXAMPLES}

The safe evaluation of an existing bridge alter being constructed 10 years is an important work for an infrastructure or bridge management system. Rule specification, and systems
Table 3. Overall structural conditions of Dah-duh bridge.

\begin{tabular}{cl}
\hline \multicolumn{1}{c}{ Item } & \multicolumn{1}{c}{ Description } \\
\hline $\begin{array}{c}\text { Date of } \\
\text { completed } \\
\text { construction }\end{array}$ & This bridge was completed in june, 1969. \\
\hline Bridge site & $\begin{array}{l}\text { This bridge locates 181K }+435 \text { of Taiwan-1 line } \\
\text { and strides over the Dah-duh river for connecting } \\
\text { the Tai-chung and Chang-hua counties. }\end{array}$ \\
\hline $\begin{array}{c}\text { Design } \\
\text { specification }\end{array}$ & $\begin{array}{l}\text { Both the AASHTO specification and the method of } \\
\text { allowable stress are applied to design. }\end{array}$ \\
\hline Superstructure & $\begin{array}{l}\text { The supporstructure is constructed by the simple } \\
\text { bridge has total length } 1000 \mathrm{~m} \text {, and width 30 m. }\end{array}$ \\
\hline Substructure & $\begin{array}{l}\text { The substructure is a sort of single column wall-type } \\
\text { concrete framework. Corrosion was adopted as foun- } \\
\text { dation and of length 16 m. }\end{array}$ \\
\hline
\end{tabular}

Cover thickness Bridge deck (top): $3.8 \mathrm{~cm}$; Bridge deck (bottom): of steel $2.5 \mathrm{~cm}$; Foundatiom: $8 \mathrm{~cm}$.

Abutment: The damage of alutment should be repaired.

Evaluation of Pier: The corrosion of steel in concrete has occurred bridge status due to not enough cover thickness.

Bridge deck: Some cracks have happened on the bridge deck.

for safe evaluation have been set up in many countries. In this study, the mathematical models for service life predicition mentioned earlier are used to evaluate the service lives of Tzyh-chyang and Dah-duh RC bridges $m$ Taiwan. Tables 2 and 3 show the overall structural conditions of Tzyh-chyang and Dah-duh bridges, respectively. According to CNS-1238 [10], concrete specimens were cored in-situ. Based on CNS-1232 [9], the compressive strength of the concrete specimens were determined and are listed in Table 4.

In this study, many parameters should be well known for using the mathematical models mentioned in Table 1 to calculate the service lives of the Tzyh-Chyang and Dah-duh bridges. Nevertheless, except the steel diameter $D=19 \mathrm{~mm}$, the compressive strength, $f_{c}^{\prime}$ (Table 4), tensile strength $f_{t}^{\prime}$ (Table 4), elastic modulus, $E_{c}$ (Table 4), and the effective elastic modulus, $E_{e f}$ (Table 4), of the concrete, corrosion current density, $i_{c o r r}$ (Tables 5 and 6), and cover thickness, $L$ (Tables 5 and 6 ), were supplied in the report. Other parameters were required as follows: the diffusion coefficient of chloride ions, $D_{c}=77$ $\mathrm{mm}^{2} /$ year $=2.44 \times 10^{-6} \mathrm{~mm}^{2} / \mathrm{s}$, the threshold value of the chloride concentration, $C^{*}=8 \mathrm{~kg} / \mathrm{m}^{3}$, the concentration of chloride ions in pores of concrete at the surface, $C_{0}=25 \mathrm{~kg} / \mathrm{m}^{3}$, the value of concrete, $\lambda=1.0 \times 10^{-2}$, creep coefficient of concrete, $\phi_{c r}=2.0$ [3], poisson's ratio, $v_{c}=0.18$ [3], the rate of rust production per unit area of plane, $j_{r}=1.5 \times 10^{-15} \mathrm{~g} / \mathrm{m}^{2}$-s [3], the density of the corrosion product, $\rho_{\text {cor }}=3600 \mathrm{~kg} / \mathrm{m}^{3}=3.6 \mathrm{~g} / \mathrm{cm}^{3}$ [3], the space of the steel bar, $s=10 \mathrm{~cm}$, and the thickness of 
Table 4. Compressive strength and properties of Tzyh-chyang and Dah-duh bridges in Taiwan.

\begin{tabular}{|c|c|c|c|c|c|c|c|c|}
\hline Bridge & $\begin{array}{c}\text { Test Point } \\
\text { No. }\end{array}$ & Test Point & $\begin{array}{l}\text { Compressive } \\
\text { strength } \\
f_{c}^{\prime}\left(k g f / \mathrm{cm}^{2}\right)\end{array}$ & $\begin{array}{c}\text { Average compressive } \\
\text { strength } \\
f_{c}^{\prime}(M P a)\end{array}$ & $\begin{array}{l}\text { Tensile } \\
\text { strength } \\
f_{t}^{\prime}(M P a)\end{array}$ & $\begin{array}{c}\text { Average tensile } \\
\text { strength } \\
f_{t}^{\prime}(M P a)\end{array}$ & $\begin{array}{c}\text { Elastic } \\
\text { modulus } \\
E_{c}(G P a)\end{array}$ & $\begin{array}{c}\text { Effective elastic } \\
\text { modulus } \\
E_{e f}(G P a)\end{array}$ \\
\hline \multirow{10}{*}{$\begin{array}{l}\text { Tzyh- } \\
\text { chyang }\end{array}$} & 1 & P3-1-1 & 263 & \multirow{10}{*}{29.97} & 2.82 & \multirow{10}{*}{3.03} & 23.87 & 7.96 \\
\hline & 2 & P13-2-1 & 212 & & 2.53 & & 21.43 & 7.14 \\
\hline & 3 & P17-2-1 & 414 & & 3.54 & & 29.94 & 9.98 \\
\hline & 4 & P22-2-2 & 372 & & 3.36 & & 28.38 & 9.46 \\
\hline & 5 & P26-2-1 & 398 & & 3.47 & & 29.36 & 9.79 \\
\hline & 6 & P29-2-2 & 253 & & 2.77 & & 23.41 & 7.8 \\
\hline & 7 & P32-1-1 & 281 & & 2.92 & & 24.67 & 8.23 \\
\hline & 8 & P36-1-1 & 328 & & 3.15 & & 26.65 & 8.88 \\
\hline & 9 & P40-2-2 & 280 & & 2.91 & & 26.62 & 8.21 \\
\hline & 10 & P44-2 & 256 & & 2.79 & & 23.55 & 7.85 \\
\hline \multirow{10}{*}{ Dah-duh } & A & P1-3 & 219 & \multirow{10}{*}{23.42} & 2.58 & \multirow{10}{*}{2.79} & 21.78 & 7.26 \\
\hline & B & P3-2 & 234 & & 2.66 & & 22.51 & 7.5 \\
\hline & $\mathrm{C}$ & P14-2 & 196 & & 2.44 & & 20.6 & 6.87 \\
\hline & $\mathrm{D}$ & P15-3 & 239 & & 2.69 & & 22.75 & 7.58 \\
\hline & $\mathrm{E}$ & P16-2 & 248 & & 2.74 & & 23.18 & 7.73 \\
\hline & F & P17-2 & 222 & & 2.59 & & 21.93 & 7.31 \\
\hline & $\mathrm{G}$ & P18-3 & 185 & & 2.37 & & 20.01 & 6.67 \\
\hline & $\mathrm{H}$ & P19-3 & 342 & & 3.22 & & 27.22 & 9.07 \\
\hline & I & P20-2 & 380 & & 3.39 & & 28.69 & 9.56 \\
\hline & $\mathrm{J}$ & $\mathrm{P} 21-3$ & 334 & & 3.18 & & 26.9 & 8.97 \\
\hline
\end{tabular}

Remark: $1.1 M P a=1 \mathrm{~N} / \mathrm{mm}^{2}=10.2 \mathrm{kgf} / \mathrm{cm}^{2} .2 . f_{t}^{\prime}=0.087 f_{c}^{\prime} .3 . E_{c}=4700\left(f_{c}^{\prime}\right)^{\frac{1}{2}} M P a .4 . E_{e f}=E_{c} /\left(1+\phi_{c r}\right), \phi_{c r}=2.0$.

pore band around the steel/concrete interface, $d_{0}=12.5 \mu \mathrm{m}=$ $12.5 \times 10^{-3} \mathrm{~mm}$. Inserting these given and suppose parameters into the formulas of Table 1 , the values of $t_{c}, t_{p}$, and $t_{c o r r}$ for the Tzyh-chyang and Dah-duh bridges were calculated and listed in Tables 5 and 6, respectively. It is worthy to point out that the computer package, i.e., Mathematica [23], should be employed to calculate the values of $t_{c}$ from the Fick second law and AJMF methods. Note that the average value of $t_{\text {corr }}$ based on the CW method [5], was adopted in this investigation, i.e, $t_{\text {corr }}=3.5$ years (Tables 5 and 6). According to (2), the maximum and minimum service lives for each pier of the Tzyhchyang and Dah-duh bridges are listed in Tables 5 and 6, i.e., $t_{\text {max }}=t_{c, \text { max }}+t_{p, \max }+t_{c o r r, \max }$ and $t_{\min }=t_{c, \text { min }}+t_{p, \min }+t_{c o r r, \min }$, respectively.

\section{DISCUSSION}

In this paper the service lives of piers for the two existing $\mathrm{RC}$ bridge exposed to chloride environment were calculated by using the mathematical models. A new formula has been proposed for calculating the depassivation time $\left(t_{p}\right)$. The findings indicate that service life of existing RC bridge can be predicted.

In such measure of $t_{c}$ values from Tables 5 and 6 , the results calculated from the Guirguis, AJMF (1) and AJMF (2) were very approached. The results of $t_{c}$ obtained from the Hookham method are larger than 2.4 2.5 times those results of $t_{c}$ gained from the method of Fick's second law. The results of $t_{c}$ obtained from the AJMF method (1) is larger than 4\% 8\% times those results obtained from the AJMF method (2). Since the Hookham method concerns parameters related to the concrete cover thickness, the predicted values for $t_{c}$ are larger than those results obtained by the other methods. The predicted maximum values for service life, $t_{\max }$ were based on the Hookham method.

In the case of $t$ values from Tables 5 and 6 , the results predicted by the proposed method were larger than 3 times those results of $t_{p}$ calculated by the Bazant method. This difference 
Table 5. Service life prediction of Tzyh-chyang bridge.

\begin{tabular}{|c|c|c|c|c|c|c|c|c|c|c|c|c|c|c|c|c|}
\hline \multirow{3}{*}{$\begin{array}{c}\text { Test } \\
\text { point } \\
\text { No. }\end{array}$} & \multirow{3}{*}{$\begin{array}{c}\text { Corrosion current } \\
\text { density } \\
i_{\text {corr }}\left(\mu \mathrm{A} / \mathrm{cm}^{2}\right)\end{array}$} & \multirow{3}{*}{$\begin{array}{c}\text { Cover } \\
\text { thickness } \\
L(\mathrm{~mm})\end{array}$} & \multicolumn{5}{|c|}{$t_{c}(\mathrm{yrs})$} & \multicolumn{2}{|c|}{$t_{p}(\mathrm{yrs})$} & \multicolumn{5}{|c|}{$t_{\text {corr }}(\mathrm{yrs})$} & \multicolumn{2}{|c|}{$\begin{array}{c}\text { Service life } \\
\text { Prediction (yrs) }\end{array}$} \\
\hline & & & \multirow{2}{*}{$\begin{array}{l}\text { Fick's } \\
\text { 2nd law }\end{array}$} & \multirow{2}{*}{$\begin{array}{c}\text { Guirguis } \\
\text { method }\end{array}$} & \multirow{2}{*}{$\begin{array}{c}\text { Hookham } \\
\text { method }\end{array}$} & \multicolumn{2}{|c|}{ AJMF method } & \multirow{2}{*}{$\begin{array}{l}\text { Bazant } \\
\text { method }\end{array}$} & \multirow{2}{*}{$\begin{array}{c}\text { Proposed } \\
\text { method }\end{array}$} & \multirow{2}{*}{$\begin{array}{c}\text { ME } \\
\text { method }\end{array}$} & \multirow{2}{*}{$\begin{array}{l}\text { Bazant } \\
\text { method }\end{array}$} & \multirow{2}{*}{$\begin{array}{c}\text { Modified } \\
\text { method }\end{array}$} & \multirow{2}{*}{$\begin{array}{c}\mathrm{CW} \\
\text { method }\end{array}$} & \multirow{2}{*}{$\begin{array}{l}\text { Weyers } \\
\text { method }\end{array}$} & \multirow[b]{2}{*}{$t_{\max }$} & \multirow[b]{2}{*}{$t_{\min }$} \\
\hline & & & & & & $\begin{array}{c}(1) \\
k=0.1\end{array}$ & $\begin{aligned} &(2) \\
& K=0.545 \\
&\end{aligned}$ & & & & & & & & & \\
\hline 1 & 0.12 & 50 & 39.5 & 64.94 & 181,29 & 66.19 & 61.35 & 14.34 & 43.02 & 31.01 & 7.96 & 9.47 & 3.5 & 37.44 & 261.75 & 57.34 \\
\hline 2 & 0.05 & 50 & 39.5 & 64.94 & 181.29 & 66.19 & 61.35 & 14.34 & 43.02 & 74.44 & 7.96 & 9.47 & 3.5 & 89.86 & 314.17 & 57.34 \\
\hline 3 & 0.05 & 50 & 42.25 & 64.94 & 181.29 & 71.59 & 66.93 & 14.34 & 43.02 & 74.44 & 7.96 & 9.47 & 3.5 & 89.86 & 314.17 & 60.09 \\
\hline 4 & 0.02 & 50 & 39.5 & 64.94 & 181.29 & 66.19 & 61.35 & 14.34 & 43.02 & 186.10 & 7.96 & 9.47 & 3.5 & 224.65 & 448.96 & 57.34 \\
\hline 5 & 0.03 & 50 & 45.13 & 64.94 & 181.29 & 77.56 & 72.92 & 14.34 & 43.02 & 124.07 & 7.96 & 9.47 & 3.5 & 149.77 & 374.08 & 62.97 \\
\hline 6 & 0.07 & 50 & 39.5 & 64.94 & 181.29 & 66.19 & 61.35 & 14.34 & 43.02 & 53.17 & 7.96 & 9.47 & 3.5 & 64.19 & 288.5 & 57.34 \\
\hline 7 & 0.06 & 50 & 39.5 & 64.94 & 181,29 & 66.19 & 61.35 & 14.34 & 43.02 & 62.03 & 7.96 & 9.47 & 3.5 & 74.88 & 299.19 & 57.34 \\
\hline 8 & 0.06 & 50 & 39.5 & 64.94 & 181.29 & 66.19 & 61.35 & 14.34 & 43.02 & 62.03 & 7.96 & 9.47 & 3.5 & 74.88 & 299.19 & 57.34 \\
\hline 9 & 0.05 & 50 & 39.5 & 64.94 & 181.29 & 66.19 & 61.35 & 14.34 & 43.02 & 74.44 & 7.96 & 9.47 & 3.5 & 89.86 & 314.17 & 57.34 \\
\hline 10 & 0.02 & 50 & 45.91 & 64.94 & 181.29 & 79.14 & 74.57 & 14.34 & 43.02 & 186.10 & 7.96 & 9.47 & 3.5 & \begin{tabular}{|l|}
224.65 \\
\end{tabular} & 448.96 & 63.75 \\
\hline & & & & & & & & & & & & & & Average & 336.31 & 58.52 \\
\hline
\end{tabular}

Table 6. Service life prediction of Dah-duh bridge.

\begin{tabular}{|c|c|c|c|c|c|c|c|c|c|c|c|c|c|c|c|c|}
\hline \multirow{3}{*}{$\begin{array}{c}\text { Test } \\
\text { point } \\
\text { No. }\end{array}$} & \multirow{3}{*}{$\begin{array}{c}\text { Corrosion current } \\
\text { density } \\
i_{\text {corr }}\left(\mu \mathrm{A} / \mathrm{cm}^{2}\right)\end{array}$} & \multirow{3}{*}{$\begin{array}{c}\text { Cover } \\
\text { thickness } \\
L(\mathrm{~mm})\end{array}$} & \multicolumn{5}{|c|}{$t_{c}(\mathrm{yrs})$} & \multicolumn{2}{|c|}{$t_{p}(\mathrm{yrs})$} & \multicolumn{5}{|c|}{$t_{\text {corr }}(\mathrm{yrs})$} & \multicolumn{2}{|c|}{$\begin{array}{c}\text { Service life } \\
\text { Prediction (yrs) }\end{array}$} \\
\hline & & & \multirow{2}{*}{$\begin{array}{l}\text { Fick's } \\
\text { 2nd law }\end{array}$} & \multirow{2}{*}{$\begin{array}{l}\text { Guirguis } \\
\text { method }\end{array}$} & \multirow{2}{*}{$\begin{array}{c}\text { Hookham } \\
\text { method }\end{array}$} & \multicolumn{2}{|c|}{ AJMF method } & \multirow{2}{*}{$\begin{array}{l}\text { Bazant } \\
\text { method }\end{array}$} & \multirow{2}{*}{$\begin{array}{c}\text { Proposed } \\
\text { method }\end{array}$} & \multirow{2}{*}{$\begin{array}{c}\text { ME } \\
\text { method }\end{array}$} & \multirow{2}{*}{$\begin{array}{l}\text { Bazant } \\
\text { method }\end{array}$} & \multirow{2}{*}{$\begin{array}{c}\text { Modified } \\
\text { method }\end{array}$} & \multirow{2}{*}{$\begin{array}{l}\mathrm{CW} \\
\text { method }\end{array}$} & \multirow{2}{*}{$\begin{array}{l}\text { Weyers } \\
\text { method }\end{array}$} & \multirow[b]{2}{*}{$t_{\max }$} & \multirow[b]{2}{*}{$t_{\min }$} \\
\hline & & & & & & $\begin{array}{c}(1) \\
k=0.1\end{array}$ & $\begin{array}{c}(2) \\
K=0.545\end{array}$ & & & & & & & & & \\
\hline A & 0.23 & 40 & 41 & 51.94 & 119.22 & 69.23 & 64.38 & 9.18 & 27.54 & 16.18 & 7.24 & 8.77 & 3.5 & 19.53 & 166.29 & 53.68 \\
\hline B & 0.05 & 40 & 41 & 51.94 & 119.22 & 69.23 & 64.38 & 9.18 & 27.54 & 74.44 & 7.24 & 8.77 & 3.5 & 89.86 & 236.62 & 53.68 \\
\hline $\mathrm{C}$ & 0.2 & 40 & 50.13 & 51.94 & 119.22 & 87.72 & 83.69 & 9.18 & 27.54 & 18.61 & 7.24 & 8.77 & 3.5 & 22.47 & 169.23 & 62.81 \\
\hline D & 0.11 & 40 & 43.33 & 51.94 & 119.22 & 73.89 & 69.13 & 9.18 & 27.54 & 33.84 & 7.24 & 8.77 & 3.5 & 40.85 & 187.61 & 56.01 \\
\hline E & 0.33 & 40 & 45.91 & 51.94 & 119.22 & 79.14 & 74.57 & 9.18 & 27.54 & 11.28 & 7.24 & 8.77 & 3.5 & 13.62 & 160.38 & 58.59 \\
\hline $\mathrm{F}$ & 0.07 & 40 & 45.13 & 51.94 & 119.22 & 77.56 & 72.92 & 9.18 & 27.54 & 53.17 & 7.24 & 8.77 & 3.5 & 64.19 & 210.95 & 58.59 \\
\hline G & 0.05 & 40 & 41 & 51.94 & 119.22 & 69.23 & 64.38 & 9.18 & 27.54 & 74.44 & 7.24 & 8.77 & 3.5 & 89.86 & 236.62 & 53.68 \\
\hline $\mathrm{H}$ & 0.06 & 40 & 39.5 & 51.94 & 119.22 & 66.19 & 61.35 & 9.18 & 27.54 & 62.03 & 7.24 & 8.77 & 3.5 & 74.88 & 221.64 & 52.18 \\
\hline I & 0.05 & 40 & 42.25 & 51.94 & 119.22 & 71.73 & 66.89 & 9.18 & 27.54 & 74.44 & 7.24 & 8.77 & 3.5 & 89.86 & 236.62 & 54.93 \\
\hline $\mathrm{J}$ & 0.04 & 40 & 43.33 & 51.94 & 119.22 & 73.89 & 69.13 & 9.18 & 27.54 & 93.05 & 7.24 & 8.77 & 3.5 & 112.33 & 259.09 & 56.01 \\
\hline & & & & & & & & & & & & & & Average & 208.51 & 56.02 \\
\hline
\end{tabular}

is caused by the different declined mechanisms of $\mathrm{Cl}^{-}$concentration. The proposed method uses a declined straight line while the Bazant method uses a declined parabolic curve. However, the real phenomenon may be that first the declined parabola curve occurs and then the declined straight line does. Based on this situation, the suitable value of $t_{p}$ is the average of results obtained by the proposed and Bazant methods.

In so far as $t_{\text {corr }}$ values from Tables 5 and 6 , the results estimated by the $\mathrm{CW}$ method were not supported by a theoretical formula. The results of $t_{\text {corr }}$ obtained from the Weyers and ME methods were very similar. In addition, Liang et al. [15] pointed out that $t_{c} \approx 4 t_{\text {corr }} \sim 5 t_{\text {corr }}$. If this is reliable, then the values for $t_{\text {corr }}$ obtained from the modified Bazant method coincide.

As a result, the Fick's second law, the average of proposed and Bazant methods, and the modified Bazant method are suggested for estimating the values of $t_{c}, t_{p}$, and $t_{c o r r}$, respectively. Based on (2) and Tables 5 and 6 , we may accept the results obtained from the service life prediction for the TzyhChyang and Dah-duh bridges of 58.82 and 56.02 years in Taiwan, respectively. This means the service life prediction coincide with $t_{\min } \leq t \leq t_{\max }$.

The method presented here is accurate, but can not be implemented in steel bridge. Moreover, our findings may be valid only for chloride environment. We suggest that similar studies be conducted with general atmospheric environment.

\section{CONCLUDING COMMENTS}

This study predicted the service lives of piers for existing $\mathrm{RC}$ bridges. A new method for estimating the depassivation 
time has presented. The service life model consists of three stages: initiation (diffusion) time, depassivation time, and corrosion (propagation) time. Among the method of Fick's second law, the average of proposed and Bazant methods, and the modified Bazant method are suggested to estimate the initiation, depassivation, and corrosion time, respectively. The results of this investigation may provide a basis for repair, strengthening, and demolition of existing RC bridges. The prediction method reported in this paper could be extended to applications for other existing RC bridges. For the sake of securing a correct prediction result, we recommend that the parameters used should be conducted in an experimented model first.

\section{ACKNOWLEDGMENTS}

The authors wish to thank the financial support of the National Science Council under contract NSC-95-2221-E-157-007.

\section{APPENDIX}

Bazant [2,3] considered the concentration of $\mathrm{Cl}^{-}, C$, as a variable of permeability depth with parabolic curve (see Fig. 3) which is a kind of the mechanism of diffusion control. However, if the concentration of $\mathrm{Cl}^{-}$is referred as the mechanism of corrosion control, then the variable of permeability depth can be represented as a declined straight line as shown in Fig. 4. From Fig. 4, when penetration depth $x<H, C$ can be expressed in terms of the similarity of triangle.

$$
C=C_{o}\left(1-\frac{x}{H}\right), x<H
$$

Differentiating (3) with respect to $x$, we obtain

$$
\frac{\partial C}{\partial x}=-\frac{C_{o}}{H}
$$

Multiplying $-D_{C}$ to (4), we have

$$
-D_{C} \frac{\partial C}{\partial x}=D_{C} \frac{C_{o}}{H}
$$

The total quality of chloride-ion in concrete can be expressed as in terms of

$$
M_{C}=\int_{0}^{H} C d x
$$

Substituting (3) into (6) and integrating (6), we obtain

$$
M_{C}=\frac{C_{o} H}{2}
$$

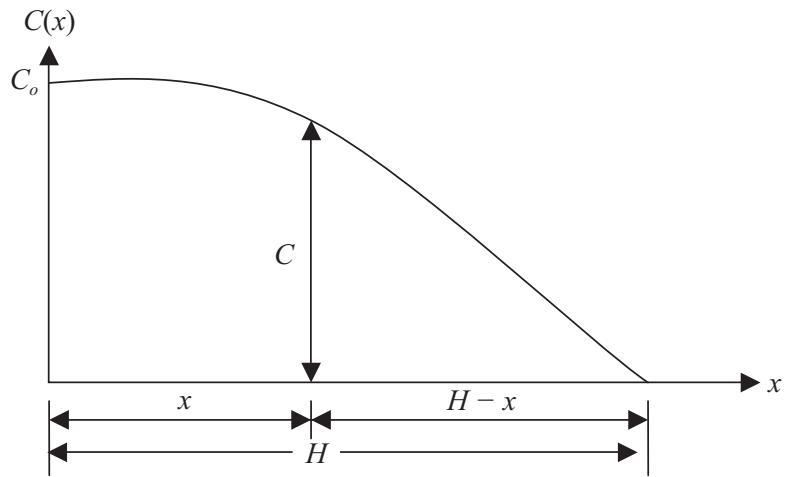

Fig. 3. Parabolic relation between $C$ and $x$.

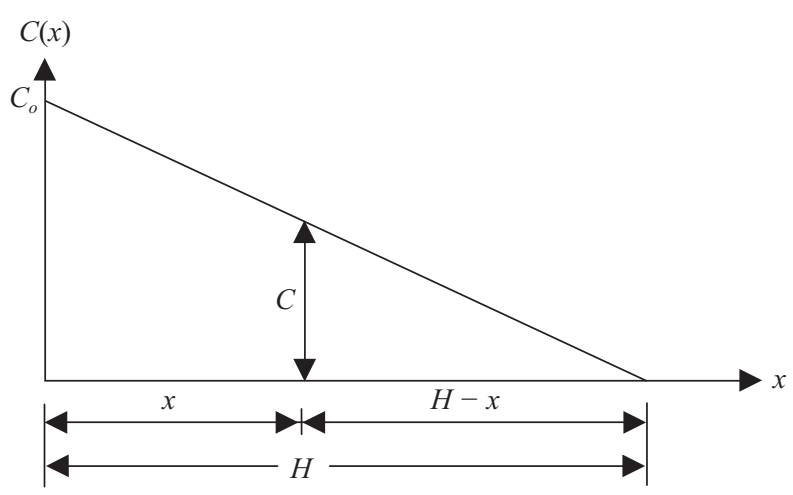

Fig. 4. Streight line relation between $C$ and $x$.

Differentiating (7) with respect to $t$, we have

$$
\frac{d M_{C}}{d t}=\frac{C_{o}}{2} \frac{d H}{d t}
$$

The flux of chloride-ion of (6) must equal $d M / d t$ at penetration depth $x<0$. Thus, we have

$$
\frac{d M}{d t}=D_{C} \frac{C_{o}}{H}
$$

Equation (8) is equal to (9), i.e,

$$
\frac{C_{o}}{2} \frac{d H}{d t}=\frac{D_{C} C_{o}}{H}
$$

After integrating to (10), we have

$$
t=\frac{1}{4 D_{C}} H^{2}
$$

If chloride-ion penetrate on the steel surface, i.e, penetration depth $x=$ concrete cover $L$, then (3) can be changed as 


$$
H=\frac{L}{\left(1-\frac{C^{*}}{C_{o}}\right)}
$$

where $C^{*}$ is the threshold of chloride concentration which is depassivated the anode surface of steel in concrete. Substituting (9) into (10), the depassivation time, $t_{p}$, can be derived as follows:

$$
t_{p}=\frac{1}{4 D_{C}}\left(\frac{L}{1-\frac{C^{*}}{C_{o}}}\right)^{2}
$$

\section{REFERENCES}

1. Amey, S. L., Johnson, D. A., Miltenberger, M. A., and Farzam H., “Temperature dependence of compressive strength of conversion-inhibited high alumina cement concrete," ACI Structural Journal, Vol. 95, No. 1, pp. 27-36 (1998)

2. Bazant, Z. R., "Physical model for steel corrosion in concrete sea structures-theory," Journal of structural Division, ASCE, Vol. 105, No. ST6, pp. 1137-1153 (1979).

3. Bazant, Z. R., "Physical model for steel corrosion in concrete sea structures-application," Journal of Structural Division, ASCE, Vol. 105, No. ST6, pp. 1155-1166 (1979).

4. Boddy, A., Bentz, E., Thomas, M. D. A., and Hooton, R. D., "An overview and sensitivity study of a multimechanistic chloride transport model," Cement and Concrete Research, Vol. 29, pp. 827-837 (1999).

5. Cady, P. D. and Weyers, R. E., "Deterioration rate of concrete bridge decks," Journal of Transportation Engineering, ASCE, Vol. 110, No. 1, pp 34-44 (1984)

6. Clifton, J. R., "Method for predicting the service life of concrete," Proceedings of the 5th International Conference on Durability of Building Materials and Components, J. M. Baker, P. J. Nixon, A. J. Majumdar, and H. Davies, eds., E\&FN Spon, London, pp. 361-373 (1990).

7. Clifton, J. R., "Predicting the service life of concrete," Report No. NISTIR 4712, Department of Commerce, National Institute of Standards and Technology, Washington, DC (1991).

8. Clifton, J. R., "Predicting the service life of concrete," ACI Materials Journal, Vol. 90, No. 6, pp. 611-617 (1993).

9. CNS-1232, "Method of test for compressive strength of cylindrical concrete specimens," Center Standerd Bureau, Department of Economics, Taiwan, pp. 1-3 (1982) (in Chinese).

10. CNS-1238, "Method of test for compressive and flexual strength of drilled cores and sawed beams of concrete," Center Standard Bureau, Department of Economics, Taiwan, pp. 1-2 (1984) (in Chinese).

11. Crank, J., The Mathematics of Diffusion, Oxford University Press, Oxford (1975).

12. Guirguis, S., "A basis for determining minimum cover requirement for durability," Concrete Durability, ACI, Detroit, pp. 447-463 (1987).

13. Hookham, C. J., "Rehabilitation of great lakes steel's no. one dock," ACI Symposium of Durability of Concrete, ACI, Detroit, (1992).

14. Liang, M. T., Lin, L. H., and Liang, C. H., "Service life prediction of existing reinforced concrete bridges exposed to chloride environment," Journal of Infrastructure systems, ASCE, Vol. 8 No. 3, pp. 76-85 (2002).

15. Liang, M. T., Wang, K. L., and Liang, C. H., "Service life prediction of reinforced concrete structures," Cement and Concrete Research, Vol. 29, pp. 1411-1418 (1999).

16. Liu, S. L. and Miau, S. K., "Corrosion of steel in concrete structures and its durability calculation," Journal of Civil Engineering, Vol. 23, No. 4, pp. 67-78 (1990) (in Chinese).

17. Liu, Y., Modeling the Time-to-Corrosion Cracking of the Cover Concrete in Chloride Contaminated Reinforcement Concrete Structure, Ph.D. Dissertation, Department of Civil Engineering, Virginia Polytechnic Institute, Blacksburg, VA (1996).

18. Liu, Y. and Weyers, R. E., "Modeling the time-to -corrosion cracking in chloride contaminated reinforced concrete structure," ACI Materials Journal, Vol. 95, No. 4, pp. 445-453 (1998).

19. Mangat, P. S. and Elgarf, M. S., "Flexural strength of concrete beams with corroding reinforcement," ACI Structural Journal, Vol. 96, No. 1, pp. 149-158 (1999).

20. Subramanian, E. V. and Wheat, H. G., "Depassivation time of steel reinforcement in a chloride environment - a one-dimensional solution," Corrosion, Vol. 45, No. 1, pp. 43-48 (1989).

21. Treadway, K., "Corrosion period," Corrosion of Steel in Concrete, P. Schiessl, ed., Chapman and Hall, London (1988).

22. Weyers, R. E., "Service life model for concrete structures in chloride-laden environments," ACI Materials Journal, Vol. 95, No. 4, pp. 445-453 (1998).

23. Wolfram Research, Inc., Mathematica User Manual, Version 3.0, 100 Trade Center Drive, Champaign, IL61820-7237, USA (1997). 